\title{
2006 ve 2013 Yılı Medya Okuryazarlığı Öğretim Programlarının Öğretmen Görüşleri Çerçevesinde Karşılaştırılması ${ }^{1}$
}

\begin{tabular}{lccc}
\hline MAKALE TÜRÜ & Başvuru Tarihi & Kabul Tarihi & Erken Görünüm Tarihi \\
Araştırma Makalesi & 10.10 .2017 & 06.07 .2018 & 07.07 .2018 \\
\hline
\end{tabular}

\author{
Pınar Tağrikulu (iD ${ }^{2}$ ve Alper Kesten \\ Ondokuzmayıs Üniversitesi
}

\begin{abstract}
Öz
Medya Okuryazarlığı dersi, öğrencilerin medya karşısında belli bir bilince erişebilmelerini sağlamayı amaçlamaktadır. Bu dersin öğretim programına konulması için yapılan çalışmalar sonrasında bir program hazırlanmış ardından bu programda bir değişikliğe gidilmesi ile 2013 yılında yeni program oluşturulmuştur. Bu çalışmada öğretmenlerden her iki öğretim programını kazanım, beceri, değer, etkinlikler ve ölçme ve değerlendirme boyutlarında değerlendirmeleri istenmiştir. Veri toplama aracı olarak nitel araştırma yöntemlerinden görüşme yöntemi kullanılmış, elde edilen veriler betimsel analiz tekniği ile değerlendirilmiştir. Genel anlamda öğretmenlerin 2013 programını 2006 programından daha kapsamlı ve işlevsel buldukları saptanmıştır. Bu noktada 2013 programını olumlu değerlendiren öğretmenlerin, programın içeriğinin hafifletilmiş olmasını ve ölçme ve değerlendirmeye olanak tanıyan bir yapıya kavuşmuş olmasını işaret ettikleri görülmüştür.
\end{abstract}

Anahtar sözcükler: Medya okuryazarlığı, ortaokul, öğretim programı, kitle iletişim.

${ }^{1} \mathrm{Bu}$ çalışma “Öğretmen görüşlerine göre yeni medya okuryazarlığı programı” isimli yüksek lisans tezinden üretilmiştir.

${ }^{2}$ Sorumlu yazar: Arş. Gör. Türkçe ve Sosyal Bilimler Eğitimi Bölümü, pinar.tagrikulu@omu.edu.tr, https://orcid.org/0000-0002-5221-6888

${ }^{3}$ Doç. Dr. Eğitim Fakültesi, Türkçe ve Sosyal Bilimler Eğitimi Bölümü, akesten@omu.edu.tr, https://orcid.org/0000-0003-2657-3168 
Günümüzde insan yaşamının hemen hemen her alanında bir yeri olan medya, gün geçtikçe kendini yenilemekte ve önemini arttırmaktadır. Sesli, yazılı, görsel ve dijital medya araçları hızla gelişmekte ve günden güne daha fazla kişiye ulaşmaktadır. $\mathrm{Bu}$ medya araçları, iletiler aracılığıyla kişileri farklı şekillerde etkileyebilmektedir (Çinelioğlu, 2013; Sevim, 2013). Kimi yazarlar tarafindan yasama, yürütme ve yargıdan sonra demokrasinin dördüncü kuvveti olarak kabul edilen medyanın, dünyada ve ülkemizde zaman zaman bu üç kuvvetin üzerinde bile etkili olduğu görülmektedir (Türk, 2013; Şeylan, 2008). Gelişen teknoloji ile birlikte medyanın yaşamımızda önemi gün geçtikçe artmakta; medya, tercihlerimiz, yaşam şekillerimiz ve düşüncelerimiz üzerinde büyük etkiler yaratmaktadır. Böylelikle medyanın etkisi bilişsel, fizyolojik hatta sosyal alanlara kadar uzanmaktadır (Şeylan, 2008).

Günümüz toplumları, günlük yaşamda iletişim araçlarının sayısının artması, değişmesi ve gelişmesi sonucu yoğun bir bilgi akışı ile karşı karşıya kalmıştır (Söylemez, 2014). Bu değişme ve gelişme ile birlikte, medya da şekil değiştirmiş artık eski medyadan (gazete, radyo, televizyon, sinema) yeni medyaya geçilmiştir. Web siteleri, çevrimiçi gazeteler, bloglar, wikiler, sosyal medya ağları, akıllı telefonlar yeni medyayı oluşturmuş, eski medyanın aksine etkileşimin çift yönlü olduğu bir yapı ortaya çıkmıştır. Artık basılı yayın organları; internet gazeteciliği ve haberciliği şekline bürünürken radyo ve televizyon kanalları da karasal yayını terk etmeye başlayarak uydu ve internet yayıncılığı yapmaya başlamıştır (Tatar, 2016; İlhan ve Aydoğdu, 2015). Geniş kitlelere hitap eden yeni medyanın çekirdeğini ise internet oluşturmaktadır. Çünkü internet teknolojisinin sunduğu etkileşim olanağı yeni medyanın ortaya çıkmasında oldukça etkili bir rol oynamıştır. İnternetin ses, görüntü ve yazı gönderme gibi olanakları sağlamasının yanında, bilgiye hızlı erişim sağlaması geleneksel medyanın dönüşümüne zemin hazırlamıştır. İnternetin oluşturduğu bu hız, güncellenebilirlik, karşılıklı etkileşim, düşük maliyet gibi üstünlükler, yeni medyanın eski medya karşısında önemli bir güç elde etmesini sağlamıştır (İlhan ve Aydoğdu, 2015; Bulunmaz, 2014).

Bilgi ve iletişim teknolojilerinde meydana gelen bu büyük ve köklü gelişmeler yaşamın her alanına yansımış, bu sayede bilgi küresel bir boyut kazanmıştır. Böylelikle iletişim araçları ve insanların birbirleri ile iletişim biçimleri değişmiş, kitle iletişim araçlarının kapsamının genişlemesiyle, iletişim ortamları farklı yapılara bürünmüştür. Yaşanan çağ ise bu gelişmeler doğrultusunda bilgi çağı, iletişim çağ1, bilişim çağı, uzay çağı, teknoloji çağı, internet çağı gibi isimlerle anılmaya başlanmıştır. Dolayısıyla bu çağda yaşayan toplumlar bilgi toplumu, teknoloji toplumu, iletişim toplumu gibi isimlerle adlandırılmışlardır (Karaman ve Karataş, 2009). Teknolojilerin gelişmesiyle bilgiye erişimin de oldukça kolaylaştığı bu çağda, erişilen bilginin doğru olup olmadığını değerlendirmek için bireylerin daha bilinçli olması gereksinimi de ortaya çıkmıştır (Som ve Kurt, 2012). Bu durum, medyadan bizlere gelen iletilerin tarafsızlığını saptayabilmek, toplumun değer yargılarının ne şekilde etkilendiğini anlayabilmek, toplum sağlığ hangi iletilerin ise zararlı olduğunu ortaya koyabilmek gibi amaçlarla bireylerde bilinç uyandırılması gerekliliğini zorunlu duruma getirmiştir (Şeylan, 2008). Bu nedenle 
çocukların ve erişkin bireylerin medya karşısında daha bilinçli olabilmeleri, medyanın kendilerine sunmuş olduğu içerikleri eleştirel gözlerle değerlendirebilmeleri bakımından medya okuryazarlığı becerilerine sahip olmaları gerektiği fikri ortaya çıkmıştır (İlhan ve Aydoğdu, 2015).

Medya okuryazarlığı; televizyon ekranından bireylere aktarılan her kareyi bir eleştiri süzgecinden geçirerek almayı, medyadan gelen her bilginin doğruluğuna hemen inanmamayı belirtmekte olan bir kavramdır (Şeylan, 2008). Bu yönü ile medya okuryazarlığ 1 "çeşitli yapılarda bulunan medyaya erişme, analiz etme, değerlendirme ve yaratma yeteneği”, bilgi üretebilme becerisi gibi boyutları kapsarken 21. yüzyıl eğitim sisteminde mutlaka kavratılması gereken bir okuryazarlık alanı olarak karşımıza çıkmaktadır (Jolls ve Thoman, 2008: 33; Aufderheide, 1993; Sur, 2012). Ancak medya okuryazarlığı yalnızca medyayı okuyup anlamayı ifade etmemekte, pek çok farklı anlamı içinde barındırmaktadır. Medya kanallarında yeniden kurgulanan iletileri ayırt etme, bu iletileri algılayarak onlarla ilgili yorumlar geliştirebilme, iletilere karşı eleştirel bir bakış açısına sahip olabilme, bu iletileri derinlemesine inceleyip, süzerek alabilme ve bu sayede kişinin kendi medya iletilerini üretebilme becerisini de içinde taşımaktadır (Çinelioğlu, 2013). Daha açık bir ifadeyle medya okuryazarlığı, medyanın mülkiyet yapısını göz önünde bulundurarak popüler kültürün işlenip yaygınlaşmasında katkılarını, politik gündemi oluşturmadaki rolünü eleştirel bir perspektifle yorumlama ve bu role karşı bir duruş alma sürecidir (Sevim, 2013). Ancak medya okuryazarlığının yalnızca kavram olarak öğrenilmesi bireylere ve topluma istenilen yararı getirmeyecektir. Bu nedenle medya okuryazarlığının eleştirel bir boyut kazanması, medya iletileri karşısında işe koşulması, bireylerin bu medya iletilerini eleştirel gözlerle değerlendirebilmeleri gerekmektedir. Böylelikle bireyler hem medyanın kendilerine sunduğu içerikleri analitik bir gözle değerlendirecekler hem de kendi kültürel metinlerini oluşturmak noktasında önemli bir adım atmış olacaklardır (Asrak Hasdemir, 2012). Bu da eleştirel medya okuryazarlı̆̆ becerilerinin ișe koșulması ile mümkün olacaktır. Bireyler bu sayede medyadan kendilerine iletilmek istenen açık ve örtük iletileri derinlemesine irdeleme firsatı yakalayabilecekler ve olumsuz içeriğe sahip olan iletilere karşı savunucu bir duruş sergileyebileceklerdir.

Medya okuryazarlığı becerisine sahip olabilmek, bireyleri pek çok konuda bu beceriye sahip olmayan bireyler karşısında bir adım öne geçirecek ve bu beceriye sahip olan bireylere gerçek ile kurguyu birbirinden ayırt edebilme yetisi kazandıracaktır (Oflaz, 2016). Medya okuryazarlığının bireylere kazandırmış olduğu bu eleştirel bakış açısı, bireylerin bilginin savunmasız alıcısı olmaktan kurtulmalarına ve bilinçli birer medya tüketicisi konumuna ulaşmalarına yardımcı olacaktır. Böylece bireyler, medyanın kendilerine ulaşan olumsuz etkilerinden kurtularak, iletişim araçlarından en etkili şekillerde yararlanabilen (Şeylan, 2008; Karaman, 2010; Karaman ve Karataş, 2009) teknoloji kullanma konusunda beceri sahibi, yaratıcı ve kendini sanatsal açıdan ifade edebilen, medyadaki zararlı içeriklere karşı kendini koruyabilen ve bu zararların farkında olan bir duruşa sahip olabileceklerdir (Buckingham, 2009). Bu veriyi kanıtlar nitelikte Scharrer (2005) çalışmasında medya 
okuryazarlı̆ğ eğitimi almanın, eleştirel tutumlar kazanma ve medyadaki şiddet olaylarını analiz edebilmede bir beceri kazandırdığını ortaya koymuştur.

İletişim teknolojilerinin gelişmesiyle günümüzde çoklu ve sınır ötesi bir iletişim ortamı şekillenmiş, hızlı bilgi akışı ve iletişim özgürlüğü sağlanırken, içerik sorunu da ortaya çıkmıştır. Medya okuryazarlığı ise bu sorunlar karşısında bir çözüm olarak görülmüştür (Avşar, 2014). Özellikle İngiltere, Kanada, Avustralya, ABD, Yeni Zelanda, Kuzey İrlanda, Rusya, Hong Kong, Japonya ve hemen hemen bütün Avrupa'da, Güney Amerika ve Afrika'da medya eğitimi bir yükseliş göstermiștir (Sevim, 2013).

Türkiye'de ise medya okuryazarlığı kavramı ilk kez 20-21 Şubat 2003 tarihinde düzenlenen iletişim şûrasında tartışılmıştır. Şûranın ardından Radyo ve Televizyon Üst Kurulu (RTÜK), Milli Eğitim Bakanlı̆̆ı (MEB), Talim ve Terbiye Kurulu Başkanlığ $($ TTKB) yetkililerinin ve medya ve etkileri alanında çalışma yapan akademisyenlerin katılımlarıyla Medya Okuryazarlığ dersi öğretim programı hazırlanması için 22 Ağustos 2006 tarihinde bir protokol imzalanmıştır. Ardından 2006 - 2007 öğretim yılında beş ilköğretim okulunda 7. Sınıflarda pilot uygulamanın başlamasına karar verilmiştir. 2007 yılının sonunda Medya Okuryazarlığı dersi öğretim programına yardımcı doküman olarak ilgili komisyon tarafından "İlköğretim Medya Okuryazarlığı Dersi Öğretmen El Kitabı" hazırlanmıştır. Bu kitapta dersi yürütmekle görevli öğretmenlere yardımcı olmak amacıyla her üniteyle ilgili gerekli kuramsal bilgilere ve çeşitli serbest yazılara yer verilmiştir. 2007 - 2008 öğretim yılında da Medya Okuryazarlığı seçmeli bir ders olarak ilköğretim okullarının ikinci kademesinde uygulanmaya başlanmıştır (Altun, 2008; Bacaksız, 2010; Elma, Kesten, Dicle, Mercan, Çınkır ve Palavan, 2009; Şahin, 2012). 2012 yılı Temmuz ayında Ankara'da medya okuryazarlı̆̆ı çalıştayı düzenlenmiştir (Söylemez, 2012). Bu çalıştayın ardından hazırlanan sonuç bildirisinde okul öncesinden itibaren bütün eğitim kademelerinde (ilkokul, ortaokul ve lise) ilgili derslerin öğretim programlarıyla ilişkilendirilerek verilmesi gerektiğine vurgu yapılmış, Medya Okuryazarlığ 1 ile ilgili program içeriklerinin sürekli yenilenmesi ve bu konuda içeriklerin saptanması için kapsaml1, bilimsel ihtiyaç analizleri yürütülmesi önerilmiştir. Medya Okuryazarlı̆̆ 1 dersinin öğretim materyallerinin, hem yazılı medya hem de diğer kitle iletişim araçları ortamlarında düzenlenmesi ise bu bildiride sunulan bir diğer öneridir (Medya Okuryazarlığı Çalıştayı Sonuç Bildirisi, 2012). Bu bildirideki önerilerden yola çıkılarak 2013 yılında Medya Okuryazarlığı öğretim programı yenilenmiştir (TTKB, 2013).

Program yenilense de eski programdan kaynaklanan birtakım sıkıntıların önüne geçilip geçilemediği ve yeni programdan istenilen verimin alınıp alınamadığ konusunda alanda yapılmış çok fazla araştırmaya rastlanmamıştır. Bu araştırma yeni program sayesinde eski programdan kaynaklanan sıkıntıların önüne geçilip geçilemediğinin ortaya konulabilmesi ve yeni programa yönelik öneriler geliştirilebilmesi amacıyla yapılmıştır. Bu doğrultuda her iki programa ilişkin sınıf içi uygulamalar öğretmen görüşleri açıssından ele alınmaya çalışılmış ve programlar 
birbirleri ile karşılaştırılmıştır. Bu kapsamda çalışmanın özellikle yeni programa yönelik yapılacak önerilerinin, program üzerinde yapılacak olan düzeltme çalışmalarına yardımcı olabileceği düşünülmektedir. Bu amaçlar doğrultusunda araştırma kapsamında seçilen Milli Eğitim Bakanlığı'na bağlı on okulda, Medya Okuryazarlığı dersini veren on iki öğretmenle görüşmeler yapılmış ve aşağıdaki araştırma sorularına yanıt aranmıştır.

1. 2006 ve 2013 Medya Okuryazarlığı dersi öğretim programları genel hatlarıyla karşılaştırıldığında her iki programın olumlu ve olumsuz yönleri nelerdir?

2. 2006 ve 2013 yılı Medya Okuryazarlığı dersi öğretim programları kazanım, beceri, değer, etkinlikler ve ölçme ve değerlendirme boyutlarında uygulamada hangi farklılıkları ortaya çıkarmaktadır?

\section{Yöntem}

$\mathrm{Bu}$ başlık altında çalışma grubu, veri toplama aracı ile verilerin toplanması ve analizi süreçleri hakkında açıklamalar yapılmıştır.

\section{Çalışma Grubu}

$\mathrm{Bu}$ araştırmanın çalışma grubunu Samsun ilinde, ilkokul ve ortaokulda görev yapmakta olan, Medya Okuryazarlığı dersine giren, farklı branşlardan on iki öğretmen oluşturmaktadır. İl çapında dersi seçen okul sayısı yetersiz olduğu için çalışma grubunun tamamına ulaşılmaya çalışılmıştır. Çalışma grubundaki öğretmenler hem 2006 programını hem de 2013 programını uygulayan öğretmenlerdir. Öğretmenlerle yapılan görüşmelerden sonra Medya Okuryazarlığı dersine ilişkin hizmet öncesi veya hizmet içi eğitim alıp almadıkları öğrenilmeye çalışılmış, çalışma grubunda yer alan öğretmenlerin hiçbirinin Medya Okuryazarlığı dersine ilişkin hizmet öncesi veya hizmet içi eğitim almadıkları belirlenmiştir. Görüşme yapılacak okulların ikisinde görev yapmakta olan öğretmenler, görüşmeye katılmak istemedikleri için çalışma grubundan çıkarılmışlardır (Tablo 1).

Tablo 1.

Araştırmaya Katılan Öğretmenler Hakkında Bilgiler

\begin{tabular}{lccccc}
$\begin{array}{l}\text { Öğretmenin } \\
\text { Kodu }\end{array}$ & Cinsiyet & Yaş & $\begin{array}{c}\text { Mezun Olduğu } \\
\text { Bölüm }\end{array}$ & Görev & Hizmet Yll \\
\hline Ö1 & E & 37 & SBÖ & Öğretmen & 13 \\
Ö2 & E & 36 & TÖ & Müdür Yar. & 15 \\
Ö3 & E & 34 & SBÖ & Öğretmen & 13 \\
Ö4 & K & 34 & SBÖ & Öğretmen & 5 \\
Ö5 & E & 50 & Coğrafya & Öğretmen & 17 \\
Ö6 & K & 37 & SBÖ & Öğretmen & 8 \\
Ö7 & K & 40 & TÖ & Öğretmen & 17 \\
\hline
\end{tabular}


Tablo 1(devam)

\begin{tabular}{lccccc}
\hline $\begin{array}{l}\text { Öğretmenin } \\
\text { Kodu }\end{array}$ & Cinsiyet & Yaş & $\begin{array}{c}\text { Mezun Olduğu } \\
\text { Bölüm }\end{array}$ & Görev & Hizmet Yılı \\
\hline Ö8 & E & 41 & TÖ & Öğretmen & 16 \\
Ö9 & K & 39 & Tarih & Öğretmen & 15 \\
Ö10 & E & 35 & SBÖ & Öğretmen & 8 \\
Ö11 & E & 45 & SÖ & Müdür & 25 \\
Ö12 & E & 50 & TÖ & Müdür & 29 \\
\hline
\end{tabular}

SBÖ: Sosyal Bilgiler Öğretmenliği; TÖ: Tarih Öğretmenliği; SÖ: Sınıf Öğretmenliği

\section{Veri Toplama Araci}

$\mathrm{Bu}$ çalışma, nitel araştırma yöntemlerinden görüşme yönteminin kullanıldığ betimsel bir çalışmadır. Öğretmenlerin 2006 ve 2013 yılı medya okuryazarlığı öğretim programlarını karşılaştırabilmeleri için bir görüşme formu hazırlanmıştır. Görüşme formunda yer alan sorular, uzman görüşüne sunulmuş ve uzmanın gerekli gördüğü düzeltmelerle son şeklini almıştır. Görüşmede katılımcılara her iki programı da değerlendirebilmelerini sağlamaya yönelik sorular yöneltilmiştir. Tüm görüşmeler ses kayıt cihazı aracılı̆̆ıyla kaydedilmiştir.

Ancak bir çalışmada yalnızca soruları hazırlamak değil, hazırlanan soruların ve yapılan görüşmenin geçerlik ve güvenirliğinin sağlanabilmesi oldukça önemlidir. Araştırılan olgu veya olay hakkında geçerli bir resim oluşturulabilmesi adına araştırmacının elde ettiği verileri ve ulaştığı sonuçları teyit ettirebilmesi için bazı ek yöntemleri (çeşitleme, katılımcı teyidi, meslektaş teyidi vb.) işe koşması gerekir (Yıldırım ve Şimşek, 2013). Araştırmacının bu yöntemleri kullanması, yapılan çalışmanın geçerliği ve güvenirliği için oldukça önemlidir. Geçerlik ve güvenirlik, türüne bakılmaksızın herhangi bir araştırmanın kavramsal çerçevesinin oluşturulması, verilerinin toplanması, analiz edilmesi ve yorumlanması ile bulgularının sunulması aşamalarında büyük önem taşıyan kavramlardır (Merriam, 2013).

$\mathrm{Bu}$ araştırma için hazırlanan görüşme formlarındaki soruların geçerlik ve güvenirliği, çalışma grubundaki öğretmenlerden önce Medya Okuryazarlığı dersini veren bir öğretmenle ön görüşme yapılması ve görüşme formunda gerekli görülen düzeltmelerin yapılmasıyla sağlanmaya çalışılmıştır. Soruların geçerlik ve güvenirliğinin belirlenmesi amacıyla yapılan bu görüşme, çalışma grubunda yer alan öğretmenlerle yapılan görüşmelerin haricinde tutulmuştur. Ayrıca elde edilen verilerin geçerlik ve güvenirliğinin sağlanabilmesi için veriler, analizler ve yorumların başka araştırmacıya sunulması yöntemi kullanılarak alanında uzman 2 öğretim elemanının görüşleri doğrultusunda çalışmaya son şekli verilmiştir.

\section{Verilerin Toplanması ve Analizi}

Verilerin toplanması için, ilgili kurumlardan izin alınmış, 2014-2015 öğretim yılında, Samsun ilinde, dersin seçildiği on okulda görev yapmakta olan ve Medya Okuryazarlığ 1 dersine giren on iki öğretmene görüşme formunda yer alan sorular 
sorulmuştur. Görüşmeler okulda öğretmenler odası ve sınıf gibi ortamlarda yapılmıştır. İstenmeden de olsa gürültü, öğretmene acil sorular sorulması gibi nedenlerle görüşmelerin bölünmesi problemleriyle karşılaşılmış ancak bu durumlar görüşme formunda yer alan soruların sorulmasına engel oluşturmamıştır. Bu bağlamda ilk önce öğretmenlere 2006 yılı Medya Okuryazarlığı öğretim programının kazanım, beceri, değer, etkinlikler ile ölçme ve değerlendirme boyutlarındaki görüşlerini açıklayabilecekleri sorular yöneltilmiştir. Daha sonra öğretmenlerden 2013 yılı Medya Okuryazarlığı öğretim programını da aynı boyutlarda değerlendirmeleri istenmiştir. Her iki programın ele alınan bütün boyutlarında olumlu görüş bildiren öğretmenler olduğu gibi olumsuz görüş bildiren öğretmenler de olmuştur. Elde edilen görüşme verilerinin analizi için her öğretmene bir kod ad verilerek öğretmenler birinci öğretmenden on ikinci öğretmene kadar Ö1, Ö2, Ö3, Ö4,... Ö12 şeklinde kodlanmışlardır. Çalışmadan elde edilen veriler betimsel analiz tekniği ile değerlendirilmiştir.

\section{Bulgular}

Öğretmenlerle yapılan görüşmelerden oluşan bu bölümde her iki öğretim programının, öğretmenlerin görüşleri ile değerlendirilmesine çalışılmıştır. Yapılan analizler sonucunda öğretmenlerin 2006 ve 2013 yılı Medya Okuryazarlığı öğretim programları hakkındaki görüşleri kazanım, beceri, değer, etkinlikler ile ölçme ve değerlendirme başlıkları altında toplanmıştır.

Öğretmenlerin 2006 ve 2013 yılı Medya Okuryazarlığı Dersi Öğretim Programlarına İlişkin Görüşleri

Araştırmanın bu bölümünde öğretmenlerin 2006 ve 2013 y1lı Medya Okuryazarlığı öğretim programlarıyla ilgili görüşlerine yer verilmiştir.

Öğretmenlerin 2006 yılı medya okuryazarlığı öğretim programına ilişkin görüşleri

Bu bölümde 2006 Medya Okuryazarlığı öğretim programının kazanım, beceri, değer, etkinlikler ile ölçme ve değerlendirme boyutlarındaki öğretmen görüşlerine yer verilmiştir.

Kazanım boyutu. Katılımcıların bir kısmı, ders için ayrılan zamana uygun nitelikte, bilgi ve kavrama düzeyine yönelik kazanımlara yer verildiğini belirtmişler ve 2006 yılı Medya Okuryazarlığı öğretim programının kazanımlarını olumlu değerlendirmişlerdir. Kazanımları olumlu değerlendiren öğretmenlerden bir kısmı, bütün medya araçlarına ayrılan zamanın yeterli olduğunu düşünmüşler ve bu durumun ders işlemelerini kolaylaştırdığını belirtmiş̧lerdir:

Ö5: Çok fazla olumsuz bir görüşüm yok eski programla ilgili. Bütün medya araçlarına ayrılan zaman yeterli. Bol bol onlar üzerinde durma şansımız var. 
Ö10: Yani daha çok bilgi seviyesine ve kavrama seviyesine yönelik kazanımlar olduğunu görüyoruz.

Ö11: Şimdi genelde çok olumsuz bir şey yok kitapta onu söyleyebilirim. Ama uygulamada olmadı̆̆ sürece bir esprisi yok. Siz istediğiniz kadar bin sayfalık çok güzel bir kitap yazın. Ama kâğıt üzerinde hepsinin olması, uygulamada her şeyin olduğunu göstermiyor. Yani bunu uygulama sahasina ayaklarl yere basar bir şekilde koymadıktan sonra bilmiyorum. Yani bence çok oturaklı bir şey olmaz diye düşünüyorum. Yoksa kazanım, beceri, değerler, etkinlikler bunların hepsi çok güzel. Yaptığım iş ĕger sahada bir işe yaramıyorsa, o zaman ben boşuna nefes tüketiyorum demektir. Fikrim yok açıkçası ama dediğim gibi yani bu kitaptaki veya bu programdaki 2006'daki her şey çok güzel. Çok net söylüyorum yani her şey çok güzel. Çünkü ders işlerken çok rahat işleyebiliyorsunuz. Ama bunun sahada uygulanabilir olması benim için elzem ve önemli. Işte o olmadı ̆̆ zaman bence bir esprisi yok yani.

Kazanımları ele alan öğretmenlerden bir kısmı kazanımların uygulamaya dönük olmadığını, yoğun olduğunu ve sadece bilgi verme düzeyinde kaldığını belirterek olumsuz yönde görüş bildirmişlerdir. Programın uygulamaya dönük olmaması en çok eleştiri alan yönüdür:

Ö8: 2006 programı bilgi merkezli. Uygulama merkezli değil de bilgi... Her ne kadar beceri, gözlem, araştırma, problem çözme gibi unsurlar var gibi gözükse de genelde uygulamaya yönelik değil.

Ö9: Kitapta yazan kazanımlarda, çocuk sanki çok aktifmiş gibi görünüyor. Yani çocuk şöyle şu kazanımı alır, şu kazanımı kazanır diye anlatıyor ama aslında çocuk o kazanımı kazanmıyor. Çünkü kazanımda verilmek istenen şey sadece bilgi. Bilgiyi veriyoruz çocuğa. Uygularsa uyguluyor. Uygulamazsa uygulamıyor. Uygulanabilirliği yok 2006 programının. Hep bildiği şeyleri tekrardan ibaret. Aktifliği yok. Çocuk oturur. Öğretmen anlatır. Ögretmen soru sorar, çocuk cevaplar. Yani klasik ders modunda.

Ö12: Kazanımlar biraz fazlayd, yoğundu. Türkiye'de belki şehir ve büyük merkezlerde okuyan çocuklara yönelik hazırlanmıs gibi geldi bana. O açıdan o program çok akademikti. Çok yoğundu.

Beceri boyutu. 2006 yılı öğretim programında yer alan becerileri ele alan öğretmenler, programın beceriler yönünden de başarılı olduğunu belirtmişlerdir. Öğretmenler, öğrencileri etkin k1lan, uygulamaya dönük ve onların günlük yaşamda işine yarayacak becerilere yer verildiğini belirtmişlerdir:

Ö3: Şimdi gözlem becerisi, araştırma becerisi, sosyal ve kültürel katılım becerisi bunlar güzel şeyler. Yani düşünülmüş. Ondan sonra herhalde eğitimin ihtiyaçlarına göre tasarlanmış. Benim buna olumsuz manada söyleyebileceğim bir şey yok. 
Ö4: Beceri bazında değerlendirdiğimizde işte öğrenciler kendi medya iletilerini üretebiliyorlar. Dediğim gibi okul gazetesi oluşturdular. Isşte bir film afişi hazırlamaya da bir klip çekme, senaryo yazma... Kendileri senaryo oluşturdular ve bundan da çok zevk aldılar.

Ö5: Yani şimdi internetin nasıl kullanılması gerektiği, bir gazeteyi nasıl okumamiz gerektiği, ondan sonra televizyon programlarindan ne kadar etkilenmeliyiz veya bunların doğru olup olmadı̆̆ını nasıl araştırabiliriz gibi ayrıntılara baktı̆̆ımızda 2006 programının daha irdelemeye açık, bu kavramları daha iyi anlamaya açı olduğunu düşünüyorum.

2006 yılı Medya Okuryazarlığı öğretim programında yer verilen becerileri olumsuz değerlendiren öğretmenler, bu becerilerin öğrencileri etkin hale getirmediğini, uygulamaya dönük olmadığını, sadece bilgi verme düzeyinde kaldığını belirtmişler ve bu becerileri yeterli görmemişlerdir:

Ö4: Evet 2006 programında ögrrencilerin sadece tartışma yetenekleri gelişiyordu. Ama yine ögrenci çok fazla aktif değildi. Metinler üzerinde çok fazla konuşuyordu.

Ö8: Bazı kazanımlarda beceriyi yazmış kazanımları istiyor ama uygulama noktasında tam bu kazanımları sağlayamiyorsunuz.

Ö9: Çocuğa bir beceri kazandırdığını çok düşünmüyorum.

Ö10: Yani burada ben beceriler konusunda herhangi bir kazanımı mesela 2006 programinda çok göremedim. Daha çok bilgiye yönelik.

Değer boyutu. 2006 yılı Medya Okuryazarlığı öğretim programında yer verilen değerleri olumlu değerlendiren öğretmenler, çocuğun günlük yaşamda işine yarayabilecek olan değerlerin ele alınmasını ve ahlaki değerlere vurgu yapılmasını kayda değer bulmuşlardır. 2006 programındaki değerleri olumsuz değerlendiren öğretmenlerin, bu değerleri yetersiz ve öğrencinin düzeyinin üzerinde buldukları görülmektedir.

Ö3: Yani bir toplum hayatında olmasl gereken bütün değerler buraya alınmış aşağı yukarı. Paylaşma, yardımlaşma, eşitlik, bilimsellik, toplumsal hayata aktif katılım, başka ne olabilir diye düşündügümde aklıma çok da fazla bir şey gelmedi yani. Bence olumlu, yeterli diye düşünüyorum.

Ö5: 2006 programında medya okuryazarlı̆̆ ile ilgili değerlerin yeterli olduğınu düşünüyorum.

Ö8: Her ikisinde de aynı değerler ahlaki değerler, etik değerler verilmiş. Her ikisinin amacında, içeriğinde ahlaki değerler var. Programın ikisinin amacı da zaten herhalde bir yönüyle ahlaki değerler. Etik değerleri vermek amaciyla yani biliyorsunuz internetteki veya bugün radyodur, radyo değil de genelde televizyonlardaki bu etik değerlere aykırı olan unsurlart 
çocuğun değerlendirmesi, hangi programı izleyip hangi programı izleyemeyeceği noktasında her ikisi de aynı amaca yönelik.

Ö4: Değerler bağlamında baktığımız zaman öğrenci doğru bilgiye nasıl ulaşacak, doğru bilgilerin güvenilirliğini nasıl test edecek... Ahlak, sorumluluk gibi açllardan yeterli. Kazanımlarda yine onlardan bahsediliyordu ama 2013 programı kadar değil. 2013 programında yasalara, etik yasalara daha fazla önem veriliyor. Aynı zamanda ön yargılar, bakış açısı, görüş, kurgulanmış medyayla gerçek medyayı şu anda daha iyi ayırt edebiliyoruz. O dönemde o şekilde değildi.

Ö9: Çocuğa değerler katmıyor diyemem. Evet, katıyor yani yardımseverlik, dürüstlük, farklılıklara saygl duyma gibi değerler katıyor. Çünkü bunu derste vermeye çallşlyoruz ama bu sadece Medya Okuryazarlı̆̆ dersinde verdiğimiz bir şey değil. Zaten diğer derslerde de verdiğimiz şeylerdi. Sosyal Bilgiler dersinin içeriğinde zaten bunlar var. O yüzden de hani Medya Okuryazarliğı çok şey kattı diyemem.

Etkinlikler boyutu. 2006 yılı Medya Okuryazarlığı öğretim programındaki etkinlikleri olumlu değerlendiren öğretmenler, etkinliklerin öğretmeni ve öğrenciyi serbest bırakan bir yapıda ve zamana yayılarak işlenebilecek nitelikte olduğunu belirtmişlerdir. Buna karşın üç öğretmenin görüşleri öğrencilerin etkin olmaması, etkinliklerin sınırlı ve yetersiz olması gibi nedenlerle olumsuz yönde olmuştur:

Ö3: Tabii etkinlikler açısından öğretmeni serbest bırakması, ögrencileri serbest burakmast artı bir özellik her zaman. Yani ögrencilerin de yapabileceği, tasarlayabileceği ve ögrretmenlerin de katkısıla ve desteğiyle yapabileceği etkinlikler var ve serbest bırakmış. Bence bu olumlu bir şey.

Ö4: Etkinliklerimiz gayet güzel.

Ö5: Etkinlik anlamında çok da eksiklik yok. Bol bol o zamanı kullanabileceğimiz etkinlikler var. İste bunların hepsini yapamasak bile büyük bir kısmını yapmaya çalışıyoruz. Bu öğrencilerin de hoşuna gidiyordu. Biz her yıl Medya Okuryazarlı̆̆ dersinin özellikle gazeteyle ilgili bölümünde ögrencilerimizle ü̧̧ dört haftayı kapsayan bir gazete hazırlama etkinliği yapıyoruz. Çocuklar, kendi çevresinde buldukları gazete haberi olabilecek nitelikteki haberleri kendileri hazırlayıp, sinıfta dört ya da beş grup oluşturup, dört tane beş tane farkl gazete çıkarlyor. (Tabii gazete konusunu işledikten sonra.) Çocukların hoşuna gidiyor. Daha görsel oluyor. Onlart sergiliyoruz sinif panosunda.

Ö4: Çok da yeterli değildi. Tamam, öğrenci yine katılımcı oluyordu ama şu andaki kadar aktif değildi. 
Ö8: 2006 programının etkinlikleri sinırl. Etkisi sinırl. Yani bazıları bazen göstermelik etkinlikler gibi yani. Çocukları işin içerisine tam olarak katamiyor.

Ö9: Çok fazla etkinliği yok 2006'nın. Çocuğun aktif olduğu bir etkinlik zaten çok fazla yok. Çocuk bir program hazırlar diye bir etkinliğini ben görmedim. Şu derste çocuk şu programı hazırlar demiyor. Hep mevcut programları değerlendiriyor ama doğrusu nedir bu nasıl hazırlanır bu verilmiyor.

Ölçme ve değerlendirme boyutu. 2006 yılı Medya Okuryazarlı̆̆ programının ölçme ve değerlendirme boyutunu olumlu değerlendiren öğretmenler, gerekçe olarak dersin ölçme ve değerlendirmesinin kolay olmasını, farklı ölçme ve değerlendirme etkinliklerine izin veren bir yapısının olmasını işaret etmişlerdir. Bazı öğretmenlerin görüşleri ise sınav yapılmaması, öğrenciye üretme becerisi katılmaması, karnede dersin notunun olmaması gibi nedenlerle olumsuz olmuştur:

Ö8: 2006'nın ölçmesinde hepsini kullanabiliyorsunuz. Sinırlama yok. İstediğiniz şekilde. Kazanımlara yönelik ölçmede sikıntı yok. Akran değerlendirme yapabiliyorsunuz. Çoktan seçmeli sorular, sinav soruları yapabiliyorsunuz. Gözlem formları düzenleyebiliyorsunuz. Ölçmede bir sikıntı görmedim 2006'da.

Ö9: Ölçme değerlendirmesi iyi çünkü böyle bir dersin ölçme değerlendirmesi kalıplara çok bağll olarak yapılmamall. 2006'da da 2013'te de iyi, güzel değerlendirmeler. Çünkü size biraklyor. Yani isterseniz proje üzerinden değerlendirin, ister testle değerlendirin, ister açık uçlu soruyla değerlendirin gözlem formuyla değerlendirin, size birakiyor çocuğu. Bu da güzel.

Ö3: Özellikle 2013 programında ürün ortaya çıkarma dikkatimi çekti. 2006'da bu yok. Ürün ortaya çıkarma, afis hazırlama işte reklam hazırlama, gazete hazırlama gibi şeyler var. Bunları değerlendirme, süreç değerlendirilmesi... Herhalde bu şekilde olur yani.

Ö9: Bu seneye kadar değerlendirmesi de yoktu zaten. Karnede not olarak görünmediği için çocukların çok da dikkate aldiğı bir ders değildi. Değerlendirme yapacağım dediğiniz zaman bile "niye ki?" sesleri yükselmeye başliyordu. Hani zaten notu yok. Bizim çocuklar malum karşıllı̆̆inda bir şey olmayınca emek sarf etmek istemiyorlar. görüşleri

Öğretmenlerin 2013 yılı medya okuryazarlığı öğretim programına ilişkin

Çalışmanın bu kısmında katılımcılardan 2013 yılı Medya Okuryazarlığı öğretim programını değerlendirmeleri istenmiştir. Programı olumlu yönde değerlendirenlerin görüşleri, programın öğrenciyi etkin bir şekilde sürece kattığı yönünde yoğunlaşmaktadır. Katılımcılar, programın etkinliklerinin, öğrencilere birtakım 
becerileri kazandırması yönünden yerinde olduğunu belirtmişlerdir. Uygulama yapabilmenin kolay olması, konularının az olması, eğlenceli olması, içeriğin hafifletilmiş olması programın öğretmenler tarafından olumlu değerlendirilmesini sağlamıştır. 2013 yılı Medya Okuryazarlığı öğretim programını değerlendiren katılımcılardan, olumlu görüş bildirenler olduğu gibi olumsuz görüş bildirenler de vardır. Her iki boyutta bildirilen görüşlere ilişkin açıklamalar çalışmanın bu kısmında ayrıntılı olarak sunulmaktadır.

Kazanım boyutu. Programın kazanımlarını olumlu değerlendiren öğretmenler, kazanımların çok ayrıntılı olmadığını, basite indirgendiğini ve sadeleştirildiğini, bu yönüyle öğrencinin düzeyine uygun duruma getirildiğini belirtmişlerdir. Öğretmenler, bu programdaki kazanımların, öğrencilerin kendi medya iletilerini üretmelerine izin verecek nitelikte olduğunu, öğrenci merkezli olduğunu, çocukların kendi isteklerine göre hareket etmelerine olanak tanıdığını, günümüze uygun, yaşamda uygulanabilir, etkili ve çok iyi planlanmış olduğunu belirtmişlerdir:

Ö3: Şimdi 2013 öğretim programı kazanımlarında öğrenci merkeze alınmış ve öğrencinin etrafinda bütün medya araçları kümelenmiş ve onun içerisinden doğruyu ve yanlışı seçme konusunda tercih ona bırakılmış, bir yol yöntem gösterilmiş. Bu açıdan ben kazanımları beğendim. Yani direkt ögrenciye o medya araçlarını nasıl kullanabilecĕgi değil de birtakım ilkeler verilmiş ve onların içerisinden doğru ve yanllşı seçmesi kendisine bırakılmış. Öğrenciyi ve bireyi merkeze alan bir yaklaşım var bu kazanımlarda.

Ö4: Kazanımlara baktı̆̆ımız zaman burada öğrencilerin kendi medya iletilerini üretmesi ya da medyanın kendine sunduğu imkânların farkına varması açısından çok önemli kazanımlarımız ve bunları gerçekten kazandırdığını düşünüyorum. Yine biraz önce söylediğim gibi buldukları bilgi doğru mu yanlış mı bunlart ayırt edebiliyorlar kazanımlarımıza baktığımı zaman. Ama en önemli fark bence kendi medya iletilerini üretebilmeleri.

Ö9: Kazanımlarl gerçekten güzel. Yani bugünümüze uygun. Şu anda gerçekten günlük hayatta kullanabilecekleri, evde ailesine karşı, arkadaşlarına karşı uygulayabilecekleri çok kazanımları var. Yani işte televizyon seyrederken "Ben bunu niye seyrediyorum acaba?" diye kendini ölçüp tartabilecek çocuk. Öyle kazanımları var ya da ailesini uyarabilecek hani "Siz şimdi bu programı niye seyrediyorsunuz? "ya da "Bu gazetede yazllan haber acaba ne kadar doğru?" "Insanlart etkilemeye mi çalışıyorlar?” Kendi ölçüp tartabileceği kazanımları var. Çok yoğun bir kazanım yok ama etkili kazanımları var. 2006'da çok sayıda kazanım vardı ama çok etkili değildi. Bunun çok sayıda değil kazanımı. Ama daha etkili kazanımlarl var. 
Ö11: Program daha sadeleştirilmiş bir şekilde duruyor yani. Ama diğeri kadar tam planlandırlmamış gördüğüm kadarıyla. Bu programda da sıkıntı yok. Yeni şeyler koyulmuş konu başlığı olarak. Yeni bir çalışma yapılmış. Ama diğerine göre çok farklı değil. Ama genel hatlarıyla bu da diğer program gibi iyi. Belirtilen meselelerde medyanın güzel yönlerinin hepsi anlattlyyor. Sorunların da hepsi üzerine parmak basilyor aslında. Dediğim gibi hepsini tek tek gösteriyor. Buradaki kazanımlarda, becerilerde, değerlerde hiçbir sorun yok. Çok iyi planlanmış.

2013 programının kazanımlarını olumsuz değerlendiren katılımcılar, ders kitabının yeterli olmadığını, kitapta ayrıntılı konulara yer verilmediğini, üst düzey kazanımların olduğunu ve tanımlara fazla yer verildiğini belirterek kazanımların olumsuz yönlerine vurgu yapmışlardır:

Ö1: Şimdi kitabın içi boş. Program olarak içi boş bir program. Kitabımız yeterli değil. Kitapta örnek eksikliği var. Kitap zengin değil.

Ö5: Yeni programda direkt programa bağll bir ders işleyeyim derseniz böyle bir konuya zaman ayırma olanağı veya böyle bir konu ayrıntılı olarak yok.

Ö6: Kazanımların çocuklar için üst düzey olduğunu düsünüyorum. Zaten Medya Okuryazarlı̆̆ ile ilgili kazanımlar ölçülemeyecek kazanımlar.

Ö7: Kazanım olarak sanki daha önceki programa göre somut öğrenmeye daha uygun ama tanımlarda çocuğu ezberciliğe itebilir. Mesela siniflandirmalar, şemalamalar, kategorilendirmeler ezberciliğe itebilir. Yine de zaman zaman dediğim gibi ezbere dayanan, çocuğun ezberlemesi gereken bilgiler olabiliyor yani.

Beceri boyutu. 2013 programının becerilerini değerlendiren öğretmenlerin olumlu buldukları yönler: Programda öğrencileri etkin hale getiren ve ölçülmesi kolay olan becerilere yer verilmiş olması, araştırma, inceleme, gözlemleme, çözümleme yapma ve üretimde bulunma olanağı tanınmasıdır. 2013 yılı Medya Okuryazarlı̆̆ 1 öğretim programındaki becerileri olumsuz değerlendiren bir öğretmen ise bu programın beceri kazandırma boyutunda yetersiz kaldığını dile getirmiştir:

Ö4: Beceri bazında değerlendirdiğimizde öğrenciler kendi medya iletilerini üretebiliyorlar. Dediğim gibi okul gazetesi oluş̧urdular. İşte bir film afiş̧ hazırlama mesela ya da bir klip çekme, senaryo... Kendileri senaryo oluşturdular ve bundan da çok zevk aldilar.

Ö7: Beceri olarak da aslinda araştırma, inceleme, onun dışında iş̧te gözlem becerileri kazandirlyor. Hani verdiği metinlerde, sorduğu sorularda da o var. Çocuğu bazı şeyleri araştırmaya itiyor. Bazı şeyleri gözlemlemeye itiyor. Bazl şeyleri de incelemeye itiyor. O anlamda fena değil diye düşünüyorum beceri konusunda ve beğeniyorum da. 
Ö8: Bir üretme var. Çözümleme var. Yani bir şey üretme ondan sonra ürettiklerini çözümleme değerlendirme gibi beceriler var 2013 'te.

Ö9: Çocuğa düşünme becerisi kattığını düşünüyorum yani. Çocuk gerçekten düşünecek ve üretecek.

Ö1: Yani 2013 'te beceri namına bir şey yok gördüğüm kadarlyla. Sadece sorun var çözüm yok.

Değer boyutu. 2013 programında yer verilen değerleri ele alan öğretmenler, bu değerlerin büyük bir emek sonucunda hazırlandığını ve öğrencilerin sorumlu yetiştirilmesine katkı sağladığını belirtmişlerdir. Değerleri olumsuz değerlendiren katılımcılar ise eksik, uygulamaya izin vermeyen bir yapının olduğunu ve ders saatinin azlığı nedeniyle değerlerin etkili şekilde öğrenciye kazandırılamayacağını açıklamışlardır:

Ö4: Değerlerde de artış var bayă̆ı bir. Öğrencileri daha sorumlu, daha farkında, daha doğru bireyler olarak yetiştirmek açısından çok önemli.

Ö9: Değerler bă̆lamında ikisindeki dĕgerler de aynı aslında yani yardımseverlik, farklılıklara saygl duyma, demokrasi... Bunların hepsi var. Ama 2013 'te daha etkili bir şekilde bunlarl öğrenecekler. 2006'da zaten her derste gördüğ̈̈müz şeyler diye bakacaklar işe. 2013'te etkili bir şekilde "bu işe yarıyormuş, evet bu doğruymuş, farklılıklara saygı duymam lazım şu yüzden.” diyerek sebebini de bilecek çocuk yaptığının.

Ö12: Vermek istedikleri değerler tabii ki toplumumuzun kültüründen, ahlaki değerlerinden, toplumsal değerlerinden süzülerek gelen değerler. Değerler tabii yani güzel hazırlanmış. Planlı, programlı şekilde büyük bir emek verilerek konulmuş.

Ö6: Hani tutum geliştirme gibi... Tamam sen çocuğun söyleminden birazcık hani düşündügünü anllyorsun ama sadece ifadede kalıyor. Çocuk kendini ifade ediyor çok güzel. Ama çocuğun tutum geliştirmesini sağlamak öyle bir ders saatinde olmuyor. Etkinlikler o değerleri vermeye yetiyor mu? Hayır. Kesinlikle hayır.

Etkinlikler boyutu. 2013 programında yer verilen etkinlikleri ele alan katılımcılar, bu etkinliklerin yararlı, öğrenci merkezli, irdeleme yapmaya izin veren, farklı derslerde de kullanılabilecek ve öğrenciyi derse güdüleyecek bir yapıda olduğunu belirtmişlerdir. 2013 programının etkinliklerini olumsuz değerlendiren öğretmenler ise bunların yetersiz, üst düzey, ağır ve kağıt üzerinde kalan bir yapıda olduğunu, öğrencilerin bu etkinlikleri kendi başlarına yapmalarının mümkün olmadığını belirtmişlerdir. Zaman açısından da bu etkinliklerin yapılmasına yetmeyecek bir sürenin bu derse ayrıldığını ifade etmişlerdir.

Ö8: Etkinlikleri gerçekten çok güzel 2013 'ün. Şimdi orada hangi etkinliği alırsanız alın öğrenci merkezli. Yani işin içerisine öğrenciyi katmış. 
Öğrenci yapacak. Yani siz yardımcı olacaksını tabii. ...Öğrenciyi bu şekilde yaparak ve yaşayarak bir sonuca ulaşmaya yönelik etkinlikler olduğunu görüyorsunuz 2013 'te.

Ö9: Oradaki etkinlikler gerçekten hep çocuğun üretmesine yönelik. Hani bizim ögrretmen olarak yapabileceğimiz şey sadece yön göstermek. Çocuk hep üretecek, hep düşünecek, hep cevaplayacak. Kendi hazırlayacak. Kendi cevaplayacak. Yanlış da kendi görecek. Öyle bir program. Benim hoşuma gitti 2013. 2013'ün etkinlikleri çok güzel zaten. Etkinlikleri güzel olduğu için faydası olacağına inaniyorum. Etkinliklerinin hepsi çok güzel. Ben hatta Sosyal Bilgiler dersi için bile yararlanmayı düşündüğ̈̈m birkaç etkinlik gördüm. Örnek vermişler programda. Güzel etkinlikleri var.

Ö10: Yani yapılan etkinliklere bakttğımızda çocukların bir broşür hazırlama, afiş hazırlama, klip hazırlama veya bir senaryoya dönüştürme gibi medya üzerinden projeler yaptıklarını görüyoruz. Yani bunu da aynı zamanda okul içerisinde, internette sergileyebiliyorlar. Medya Okuryazarlı̆̆ dersi verildikten sonra medya okuryazarlığ șenliği diye bir etkinliğin yapılmast gerektiği programda belirtiliyor ve bunun tüm ögrencilerle okulda sergilenmesi hedefleniyor. Tabii bu hem çocuklara "başardım" duygusu, "başarabildim" duygusu verebilmesi açısından önemli hem de diğer ögrrenciler açısından çocukların bu şekilde yeni yeni projeler üretmesi, onları da bu Medya Okuryazarlğ̆ dersi için özendirebilir.

Ö6: Etkinlikler dediğim gibi çok güzel ama çocuk benim rehberliğim olmadan bir etkinliği kendi başına yapamıyor. Çünkü üst düzey. Zaten ilkokulda da Sosyal Bilgiler dersi ihmal ediliyor. Aslinda ilkokulda da iletişim dersi var ama Matematik ve Türkçe, sözelde, saylsalda hep ön planda olduğu için Fen ve Sosyal Bilgiler biraz ilkögretimde geri atıllyor. Sonra çocuk bize eksik bir şekilde geliyor. Biz eksik bir çocuğa hiç karşılaşmadığı bir dersi sunuyoruz ve etkinlikler çocuklara çok ağır geliyor.

Ölçme ve değerlendirme boyutu. 2013 programını ölçme ve değerlendirme açısından değerlendiren öğretmenler, programa sınav konulmasının ve proje yapma zorunluluğu getirilmesinin dersin ciddiye alınma oranını arttırdığını, daha fazla etkinliğe yer verildiği için değerlendirmenin basit olduğunu belirtmişlerdir:

Ö1: Belki seçmeli derslere sinav koyulmasının en güzel tarafi bu oldu. Biraz daha belki ciddiye ald öğrenciler yani.

Ö6: Ölçme değerlendirmesi etkinlik olduğu için basit. Yani kolay. Zaten etkinlik olduğunda ölçme de kolay oluyor. Yani elinizin altında tek bir tane değil, birkaç tane veri oluyor. O zaman daha doğru bir ölçme şekli oluyor. Yani beceriler yönünden ölçmeye müsait. 
Ö9: Etkinliği fazla olduğu için ölçme değerlendirmeyi daha güzel yapacă̆ız. Çocuk da emeğinin karşılı̆̆ını alacak. Bu etkinliğin, emeğin karşılı̆̆ında bir ölçmesi, değerlendirmesi olacak. Bilecek ki yaptı̆̆ şey değerlendiriliyor. Hani böyle oturup dersi dinledim... Bu değerlendirilmeyecek. Çocuğun etkinliğ dĕ̆erlendirilecek. Bizi hiç kısıtlamıyor. O çok güzel. Ölçme değerlendirmede kısıtlama yok. Istediğiniz gibi değerlendiriyorsunuz.

Ö10: Evet şimdi yeni yapılan değişiklikle birlikte Medya Okuryazarlı̆̆ dersinin önemi de arttı açıkçası. Çünkü önceden öğrenciler seçmeli dersleri-Medya Okuryazarlığı da seçmeli bir ders olduğu için-daha az önemli dersler gibi görüyorlardı. Şu anda onlar için de birer yazılı veya proje yapma zorunluluğu olduğu için Medya Okuryazarlı̆̆ dersinin öneminin arttı̆̆ını düşünüyorum ben.

2013 programının ölçme ve değerlendirme boyutunda olumsuz görüş bildiren katılımcılar, uygulama yapılamadığını, seçmeli ders olduğu için Medya Okuryazarlığı dersinin önemsenmediğini, bir katılımcı ise bu ders için sınav yapılmasını gerçekçi bulmadığını ve not verilecek şekilde bir ölçme yapılmasına gerek olmadığını belirtmiştir:

Ö1: Ölçme olarak şimdi şöyle bir sıkıntımız var. Konular birbirine çok yakın olduğu için genelde test tekniğini tercih ediyoruz. Genelde hep aynı soruların tersten çevrilip sorulması gibi bir şey oluyor.

Ö7: Zaten seçmeli ders olması çocuğun gözünde Medya Okuryazarlı̆̆ dersinin önemini aslında azaltıyor.

Ö11: Bu derste mesela ölçme değerlendirme yaptık biz birinci dönem bir test hazırladık. Yaptık ama çok gerçekçi bulmadım ben açıkçası. Çünkü bu dersin ölçme değerlendirmesinin kâğıt üzerinden yani notla yapılması bana garip geldi. Bana ölçme yani bir sınav ve bir not meselesi çok gerçekçi gelmiyor açık söylemek gerekirse. Bunun notla ölçülmesi gereken bir ders olduğunu düşünmüyorum. Bu bence ölçme değerlendirme kıstaslarlyla ölçülmemesi gereken, en azından not bazında ölçülmemesi gereken bir şey.

\section{Tartışma, Sonuç ve Öneriler}

Her gün binlerce iletisine ulaşılan medyadan en doğru şekilde yararlanabilmek

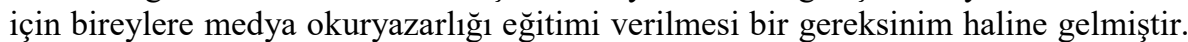
$\mathrm{Bu}$ gereksinim doğrultusunda okullarda Medya Okuryazarlığı dersi verilmeye başlanmıştır. Yurtdışında ülkemizden daha önce gündeme gelen bu dersin etkilerinin ülkemize ulaşması ise zaman almıştır. Medya okuryazarlığı eğitimi, medya araçlarından gelen etkileri nesnel gözlerle değerlendirip bu etkilerin olumlu yönüne odaklanmayı hedeflemektedir. Ancak yine de medya okuryazarlığı eğitimi, yalnızca medya araçlarından gelen olumlu ve olumsuz etkileri değerlendirmeyi veya bu 
araçları kullanmayı öğretmemektedir. Yaşamın tüm alan ve kesitlerinde meydana gelen olay ve olguları anlama, açıklama ve yorumlama becerisi de medya okuryazarlığının kazandırmaya çalıştığı beceriler arasında yerini almaktadır (Elma, Kesten, Dicle ve Uzun, 2010).

Ülkemizde Medya Okuryazarlığı dersinin geldiği noktaya bakıldığında, dersin istenen başarıya ulaşamadığı görülmektedir. Şeylan'ın (2008) çalışmasında Medya Okuryazarlığ 1 dersinin uğradığı bu başarısızlığa neden olarak benimsenen korumacı eğitim modeli, politik ve sosyolojik gündemlerin derslerde yer almamas1, öğretmenlerin yetersizliği ve teknik donanım eksikliği gösterilmiştir. Ancak Medya Okuryazarlığı dersinde ortaya çıkan bu başarısızlığın temelinde başka nedenler de bulunmaktadır. Öğretim programında yer alan birtakım eksiklikler de dersin istenen başarıya ulaşmasına engel oluşturmaktadır. Radyo ve Televizyon Üst Kurulu'nun (2016) öğrenciler ile yapmış olduğu çalışmada, dersin işleniş biçiminde ve ders kitabının içeriğinde geliştirilmesi gereken yönler olduğu ortaya konulmaktadır. Bu kapsamda öğrenciler, dersin ve ders kitabının içeriğinin arttırılması, gerekli medya araç gereçlerinin derse zamanında getirilmesi, dersin uygulamalı olması, etkinlik şeklinde ve bilgisayardan işlenmesi, eğlenceli bir yapıya kavuşturulması gibi noktalara vurgu yapmışlardır. Bu öneriler dersin süreç içerisinde istenen başarıya ulaşamaması noktasında ne gibi eksiklikler olduğunu ortaya koymaktadır. Programdan kaynaklanan eksiklikler ise programın kazanım, beceri, değer, etkinlikler ile ölçme ve değerlendirme boyutlarında görülebilen eksikliklerdir. Bu çalışmanın sonuçlarına bakıldığında 2013'te yayımlanan programın öğretmenler tarafından daha başarılı bulunduğu ve bu eksiklikleri kısmen giderdiği söylenebilir. 2006 yılında hazırlanan programın 2013 'te yeniden düzenlenirken arada kalan yıllarda yayımlanan makalelerdeki eleştirileri de göz önünde bulundurarak hazırlanmış olmasının da çalışmaya katılan öğretmenlerin olumlu görüş bildirmelerinde etkisi olduğu düşünülmektedir.

Çalışmaya katılan öğretmenler, kazanımlar boyutunda yaptıkları değerlendirmelerde, 2006 programındaki kazanımların 2013 programındaki kazanımlardan daha fazla bilgi merkezli ve yoğun içerikli olduğunu vurgulamış, 2013 programının bu anlamda daha fazla öğrenci merkezli ve sadeleştirilmiş bir yapıda olduğunu söylemişlerdir. 2013 programındaki kazanımların sayısının 2006 programındaki kazanımlardan daha az olduğu ve 2013 programının daha fazla etkinlik yapmaya olanak tanıyan bir yapısının olduğu göz önüne alındığında, öğretmenlerin bu konudaki görüşlerinin haklı gerekçelere dayandığı görülmektedir.

Öğretmenler her iki programın beceri boyutunu değerlendirdiklerinde ise 2006 programının öğrencilere yoğun bir bilgi aktarımı yaptığı için beceri öğretiminde başarısız olduğunu, 2013 programının ise hafifletilmiş içeriği sayesinde bilgi aktarımının yanında beceri öğretiminde de başarılı olduğunu belirtmişlerdir. Söylemez (2012) çalışmasında Türkiye'de 2006 öğretim programında medya okuryazarlığı becerilerine yeteri kadar önem verilmediğine vurgu yapmıştır. Bu yönüyle çalışmalarda elde edilen bulgular benzerlik göstermektedir. 2006 
programında Medya Okuryazarlığı dersine ayrılan sürenin bir saat, verilmeye çalışılan kazanımların ise oldukça yoğun olduğu bilinmektedir. Buna karşılık 2013 programında verilmek istenen kazanımların hafifletildiği ve ders saatinin de ikiye çıkarıldığı görülmektedir. Medya Okuryazarlığı dersine ilişkin yapılan çalışmaların (Elma vd. 2009, Elma vd. 2010, Altun, 2009) neredeyse tamamında 2006 programının fazla bilgi temelli olduğu ve sürenin yetersiz olduğuna ilişkin bulguların 2013 programında kısmen de olsa göz önünde bulundurulmuş olmasının, öğretmenlerin 2006 programı için eleştiri konusu ettikleri bu konularda görüşlerinin değişmesinde etkili olduğu görülmektedir.

2006 ve 2013 yılı Medya Okuryazarlığı öğretim programlarının öğrencilere kazandırmaya çalıştığı değerler öğretmenler tarafından ele alındığında, her iki programın da değer öğretimini sağlamak konusunda başarılı olduğu belirtilmiştir. Her iki programın etkinlikler boyutu ele alındığında ise öğretmenlerin olumsuz eleştirilerinin daha çok 2006 programı üzerinde yoğunlaştığı görülmüştür. 2006 programının öğrenci merkezli olmadığı, dolayısıyla öğrenciyi etkin kılmak noktasında yetersiz kaldığı vurgulanmıştır. Apak (2008) ve Çakmak (2010) çalışmalarında Medya Okuryazarlığı öğretim programının daha çok medya araçları merkezli bir yaklaşım ortaya koyduğunu ve bu yönüyle öğrencilere etkinliklerde bulunmaya izin vermeyen korumacı bir yaklaşıma sahip olduğunu ortaya koymuşlardır. Altun (2009) çalışmasında Medya Okuryazarlığı öğretim programını değerlendirdiğinde her kazanımla ilgili etkinliğe yer verildiğini saptamış ancak bu etkinliklerin önemli bir kısmının değerlendirme yapmaya yönelik ve yetersiz olduğunu ya da hiçbir çalışmaya yer verilmediğini belirtmiştir. Altun'un (2009) bulguları da bu anlamda çalışmanın bulgularını destekler nitelikte veriler sunmaktadır. Buna karşılık 2013 programının ise öğrenciyi daha çok merkeze alan bir yapısının olduğu ve öğrenciye bol bol etkinlik yapma şansı tanıdığı ortaya konulmuştur. Bu durum, öğretmenlerin 2013 programını etkinlikler boyutunda 2006 programından daha olumlu değerlendirmeleri üzerinde önemli bir etken olarak değerlendirilebilir. Öğrenci merkezli eğitimin günümüzde oldukça önemsendiğinden hareketle öğretmenlerin bu değerlendirmeleri, kendilerinin de eğitimde güncel yaklaşımları takip ettiklerini ve benimsediklerini düşündürmektedir.

Ölçme ve değerlendirme boyutunda ise yine en çok eleştiriye maruz kalan program 2006 programı olmuştur. Ölçme ve değerlendirmeye izin vermeyen bir yapıya sahip olması nedeniyle öğrenciler tarafından ciddiye alınmaması programın zayıf yönü olarak gösterilmektedir. Altun (2009) 2006 yılı Medya Okuryazarlığı öğretim programında alternatif değerlendirme yöntemlerine yer verildiğini ancak bu yöntemlerin özel olarak medya okuryazarlığı eğitimi çerçevesinde nasıl ele alınacağı ile ilgili yönlendirmeler bulunmadığını belirterek ilgili bulguyu desteklemektedir. Buna karşılık 2013 programı ile birlikte Medya Okuryazarlığı dersi için bir sınav yapma koşulunun getirilmiş olduğu, böylelikle dersin öğrenciler tarafından ciddiye alınmasının sağlandığı öğretmenlerin vurgu yaptığı bir konudur. Dolayısıyla eski programın ölçme ve değerlendirme boyutunda var olan birtakım sorunların aşılmasında sınav yapılması koşulu önemli bir etken olarak gösterilmiştir. Seven ve 
Engin'in (2008) çalışmalarında vurguladıkları nokta da öğretmenlerin bu konudaki düşüncelerini onaylar niteliktedir. Bu çalışmada iyi bir öğrenmenin gerçekleşebilmesi için öğrencinin derse karşı dikkatli olması gerektiği, bu dikkatin de pekiştirme ve kaygılandırma yolu ile güdülenerek sağlanabileceği vurgulanmıştır. Bu güdülenmeyi sağlayacak olan en önemli aracın da not olduğunun belirtildiği bu çalışma, öğretmenlerin düşünceleri ile aynı doğrultuda veriler sunmaktadır. Belli bir seviyede olan kaygının öğrenmede etkili olduğu, sınavın da öğrenciler üzerinde kaygı oluşturan bir etmen olduğu düşünüldüğünde öğretmenlerin düşünceleri desteklenmiş olmaktadır.

Elde edilen tüm verilerden yola çıkılarak 2013 programının genel hatlarıyla 2006 programındaki bazı eksiklikleri giderdiği ve öğretmenlerin görüşleri doğrultusunda daha başarılı bir program olduğu söylenebilir. 2013 programının yapılandırmacı yaklaşıma daha uygun bir yapıda hazırlanmış olması, öğretmenlerin bu programı daha olumlu yönde değerlendirmelerini sağlamış olabilir. Ancak yine de 2013 programının tamamı ile kusursuz olduğunu söylemek mümkün değildir. Programın sadeleştirilmiş içeriğinin "boş" olarak değerlendirilmesine sebebiyet vermesi, etkinlik ağırlıklı bir program olmasına rağmen öğretmenlerin bu derste ne tür etkinlikler yapabileceklerinden haberdar olmamaları buna kanıt niteliğindedir. Ayrıca dersin hâlâ seçmeli dersler havuzunda yer alması, dersin kimin vereceğinin net olarak belli olmaması ve dersin genellikle "ders saatini dolduramayan öğretmenler" tarafindan verilmesi ya da "okul müdür ve müdür yardımcılarının ders saatini doldurmak" için kullanılıyor olması gibi sorunların mevcut yapı içinde değiştirilmediği de belirlenmiştir. $\mathrm{Bu}$ nedenle öğretmenlere de hizmet içi eğitim verilerek dersin işleyişinden haberdar edilmeleri yerinde bir yaklaşım olacaktır. Çünkü iyi bir medya okuryazarlığ $\breve{1}_{1}$ eğitiminin verilmesinin yolu öncelikle eğitimcilerin medya okuryazarlığı becerilerine sahip olup bunları deneyimlerinde de ortaya koymalarından geçmektedir (Elma vd., 2009; Altun, 2009; Oflaz, 2016; Kurt ve Kürüm, 2010; Deveci ve Çengelci, 2008; Ardıç, 2016). Ancak bu noktada yalnızca öğretmen olmuş kişilere değil öğretmen olmaya aday kişilere de Medya Okuryazarlı̆̆ı konusunda bir bilinç kazandırılması ve Medya Okuryazarlık düzeylerinin arttırılması sağlanmalıdır. $\mathrm{Bu}$ amaçla hizmet öncesi eğitim programları düzenlenerek öğretmen adaylarının bu programlara katılımları sağlanmaya çalışılmalıdır (Çepni, Palaz ve Ablak, 2015).

$\mathrm{Bu}$ araştırmada Medya Okuryazarlığı dersini vermiş ve vermekte olan öğretmenlerden Medya Okuryazarlığı öğretim programı'nın farklı boyutları hakkında görüşlerini bildirmeleri istenmiş, çalışma bu görüşler çerçevesinde ele alınmıştır. Ancak ileride yapılacak olan farklı çalışmalarda öğrenci görüşleri alınarak veya ders içi gözlemler yapılarak Medya Okuryazarlığı dersine ilişkin değerlendirmelerin kapsamı genişletilebilir. Ayrıca ders kitabı da olmayan bu programın daha etkili bir şekilde uygulanabilmesi için bu derse özel bir Medya Okuryazarlı̆̆ Etkinlik Kitabı yayımlanmasının yararlı olabileceği düşünülmektedir. Medya Okuryazarlığı dersinin seçmeli ders kapsamından çıkarılarak zorunlu ders kapsamına alınmasının, eğer ders olarak kalmaya devam edecekse dersin ciddi bir şekilde Sosyal Bilgiler ya da Türkçe öğretmenleri veya İletişim Fakültesi mezunu olup öğretmenlik sertifikası almış olan 
kişiler tarafından verilmesinin sağlanması ve merkezi sınavlarda Medya Okuryazarlığı dersinden soru sorulmasının da dersin öğrenciler tarafından ciddiye alınması noktasında etkili olabileceği düşünülmektedir. Çalışma grubunda yer alan öğretmenlerden üçü okullarda yönetim görevinde bulunmaktadır. Bütün (2010) çalışmasında okulda yönetim görevi olan öğretmenlerin Medya Okuryazarlığ dersini verdiğini ancak bu durumun dersten yeterli verim alınması önünde engel oluşturduğunu belirtmiştir. İlgili çalışmanın bu bulgusundan hareketle dersin okullarda yönetim görevleri yapmakta olan öğretmenlerden çok yönetim görevi olmayan öğretmenlere verilmesinin dersten yeterli verim alınması noktasında yararlı olabileceği belirtilebilir. 


\section{Kaynakça}

Altun, A. (2008). Türkiye'de Medya Okuryazarlığı. İlköğretmen Ĕgitimci Dergisi, 16, 30-34.

Altun, A. (2009). Eğitim Bilim Açısından Seçmeli Medya Okuryazarlığı Dersi Programına Eleştirel Bir Yaklaşım. Ahi Evran Üniversitesi Ĕ̆itim Fakültesi Dergisi, 10(3), 97-109.

Apak, Ö. (2008). “Türkiye, Finlandiya ve İrlanda İlköğretim Programlarının Medya Okuryazarlığı Eğitimi.” Yayımlanmamış yüksek lisans tezi, Kocaeli Üniversitesi Sosyal Bilimler Enstitüsü, Kocaeli.

Ardıç, E. (2016). "Medya Okuryazarlığı ile İlgili Lisansüstü Çalışmaların Karşılaştırmalı İncelemesi: Türkiye, ABD ve Kanada Örneği.” Yayımlanmamış yüksek lisans tezi, Abant İzzet Baysal Üniversitesi Eğitim Bilimleri Enstitüsü, Bolu.

Asrak Hasdemir, T. (2012). Gelenekselden Yeni Medya Okuryazarlığına: Türkiye Örneğinde Bir Değerlendirme. Hitit Üniversitesi Sosyal Bilimler Enstitüsü Dergisi, 5(2), 23-40.

Aufderheide, P. (1993). Media Literacy. A Report of the National Leadership Conference on Media Literacy. http://eric.ed.gov/?id=ED365294 adresinden erişilmiştir.

Avşar, Z. (2014). Medya Okuryazarlığı. İletişim ve Diplomasi Dergisi, 2.

Bacaksız, T. (2010). “Medya Okuryazarlığı Dersinde Gazete ve Dergi Kullanımı İzmir'de Medya Okuryazarlığı Dersinin Öğrencilerin Gazete ve Dergi Okuma Alışkanlıklarına Olan Etkisi." Yayımlanmamış yüksek lisans tezi, Gazi Üniversitesi Sosyal Bilimler Enstitüsü, Ankara.

Buckingham, D. (2009). The Future of Media Literacy in The Digital Age: Some Challenges for Policy and Practice. medienimpulse-online. http://www.medienimpulse.at/pdf/Medienimpulse_THE_FUTURE_OF_MEDI A_LITERACY_IN_THE_DIGITAL_AGE_SOME_CHALLENGES_FOR_ POLICY_AND_PRACTICE_Buckingham_20091207.pdf adresinden erişilmiştir.

Bulunmaz, B. (2014). Yeni Medya Eski Medyaya Karşı: Savaşı Kim Kazandı ya da Kim Kazanacak. Karadeniz Teknik Üniversitesi İletişim Araştırmaları Dergisi, 4(7), 22-29.

Bütün, E. (2010). “Türkiye'de Medya Okuryazarlığı Dersine İlişsin Öğretmen, Öğrenci ve Veli Görüşleri: Samsun İli Örneği.” Yayımlanmamış yüksek lisans tezi, Ondokuz Mayıs Üniversitesi Eğitim Bilimleri Enstitüsü, Samsun. 
Çakmak, E. (2010). "İngiltere ve Türkiye'deki İlköğretim Medya Okuryazarlığı Eğitimi Program ve Uygulamalarının Karşılaştırmalı Olarak İncelenmesi.” Yayımlanmamış doktora tezi, Abant İzzet Baysal Üniversitesi Sosyal Bilimler Enstitüsü, Bolu.

Çepni, O., Palaz, T. ve Ablak, S. (2015). Sosyal bilgiler öğretmen adaylarının medya ve televizyon okuryazarlık düzeylerinin çeşitli değiş̧enlere göre incelenmesi. Turkish Studies, 10(11), 431-446.

Çinelioğlu, G. (2013). "Sosyal Bilgiler Öğretmen Adaylarının Medya Okuryazarlığı Dersine Yönelik Tutumlarının İncelenmesi.” Yayımlanmamış yüksek lisans tezi, Balıkesir Üniversitesi Sosyal Bilimler Enstitüsü, Balıkesir.

Deveci, H. ve Çengelci, T. (2008). Sosyal Bilgiler Öğretmen Adaylarından Medya Okuryazarlığına Bir Bakış. Yüzüncü Yll Üniversitesi Eğitim Fakültesi Dergisi. 5(2), 25-43.

Elma, C., Kesten, A., Dicle, A, N., Mercan, E., Çınkır, Ş. ve Palavan, Ö. (2009). İlköğretim 7. Sınıf Öğrencilerinin Medya ve Medya Okuryazarlığı Dersine İlişkin Tutumları. Ondokuz Mayıs Üniversitesi Eğitim Fakültesi Dergisi. 27, 93113.

Elma, C., Kesten, A., Dicle, A. N. ve Uzun, E. M. (2010). Türkiye'de Medya Okuryazarlı̆̆ı Eğitimi: Medyanın İşleyişi ve Etik İlkeler Açısından Bir Değerlendirme. Kuram ve Uygulamada Eğitim Bilimleri, 10(3), 1409-1458.

İlhan, E. ve Aydoğdu, E. (2015). Medya Okuryazarlığı Dersi ve Yeni Medya Algısına Etkisi. Erciyes İletişim Dergisi, 4(1), 52-68.

Jolls, T. ve Thoman, E. (2008). 21. Yüzyll Okuryazarlı̆g: Medya Okuryazarllğına Genel Bir Bakış ve Sinıf İ̧̧i Etkinlikler. (Çev: C. Elma ve A. Kesten). Ankara: Ekinoks Yayınevi.

Karaman, M. K. (2010). Öğretmen Adaylarının TV ve İnternet Teknolojilerini Kullanma Amaç ve Beklentilerinin Medya Okuryazarlı̆ğ Bağlamında Değerlendirilmesi. Uşak Üniversitesi Sosyal Bilimler Dergisi, 3(2), 51-62.

Karaman, M. K. ve Karataş, A (2009). Media Literacy Levels of the Candidate Teachers. Elementary Education Online, 8(3), 798-808.

Kurt, A. A. ve Kürüm, D. (2010). Medya Okuryazarlığı ve Eleştirel Düşünme Arasındaki İlişki: Kavramsal Bir Bakış. Mehmet Akif Ersoy Üniversitesi Sosyal Bilimler Enstitüsü Dergisi, 2(2), 20-34.

Medya Okuryazarlığı Çalı̧̧̧ayı Sonuç Bildirisi, (2012) http://www.medyaokuryazarligi.org.tr/cal9.html adresinden erişilmiştir. 
Merriam, S. B. (2013). Nitel Araștırma: Desen ve Uygulama İçin Bir Rehber (1. Baskı). (Çev: S. Turan). Ankara: Nobel Yayıncılık. (Özgün kitap 1988'de yayımland1.)

Oflaz, T. (2016). "Medya Okuryazarlığı Dersi Kapsamında Öğrencilerin, Medyaya Bakış Açılarının Değerlendirilmesi: Denizli İl Örneği.” Yayımlanmamış yüksek lisans tezi, Yaşar Üniversitesi Sosyal Bilimler Enstitüsü, İzmir.

Radyo ve Televizyon Üst Kurulu (2016). Medya Okuryazarlı̆̆ Araştırması, T.C. Radyo ve Televizyon Üst Kurulu Kamuoyu, Yayın Araştırmaları Ve Ölçme Dairesi Başkanlı̆̆ı, Ankara. https://www.medyaokuryazarligi.gov.tr/userfiles/files/Medya\%20Okuryazarlig i\%20Arastirmasi\%202015(1).pdf adresinden erişilmiştir.

Scharrer, E. (2005). Sixth Graders Take on Television: Media Literacy and Critical Attitudes of Television Violence. Communication Research Reports, 22(4), 325333.

Seven, M. A. ve Engin, A. O. (2008). Öğrenmeyi Etkileyen Faktörler. Atatürk Üniversitesi Sosyal Bilimler Enstitüsü Dergisi, 12(2). 189-212.

Sevim, F. (2013). "Medya Okuryazarlı̆̆ı, Toplumsal Cinsiyet ve Kadının Medyada Temsili." Yayımlanmamış yüksek lisans tezi, İstanbul Ticaret Üniversitesi Sosyal Bilimler Enstitüsü, İstanbul.

Som, S. ve Kurt, A. A (2012). Bilgisayar ve Öğretim Teknolojileri Eğitimi Bölümü Öğrencilerinin Medya Okuryazarlık Düzeyleri. Anadolu Journal of Educational Sciences International, 2(1), 104-119.

Söylemez, Y. S. (2012). “Asya ve Okyanusya Ülkelerinde Medya Okuryazarlı̆g 1 Eğitimi: Türkiye ve Yeni Zelanda Karşıllaştırması." Yayımlanmamış yüksek lisans tezi, Kocaeli Üniversitesi Sosyal Bilimler Enstitüsü, Kocaeli.

Söylemez, Y. S. (2014). Malezya'da Medya Tüketimi ve Medya Okuryazarlı̆g 1 Uygulamaları. Erciyes İletişim Dergisi, 3(3), 98-118.

Sur, E. (2012). “İlköğretim İkinci Kademe Öğretmen ve Öğrencilerinin Medya Okuryazarlığına İlişkin Görüşleri. ” Yayımlanmamış yüksek lisans tezi, Niğde Üniversitesi Eğitim Bilimleri Enstitüsü, Niğde.

Şahin, M. (2012). "Medya Okuryazarlığı Dersi Alan ve Almayan İlköğretim Okulu Öğrencilerinin Medya Tüketim Alışkanlıkları Farklılaşması." Yayımlanmamış yüksek lisans tezi, Marmara Üniversitesi Sosyal Bilimler Enstitüsü, İstanbul.

Şeylan, S. (2008). "Medya Okuryazarlığı Ders Uygulamalarında Dünya Üzerinde Görülen Aksaklıklar." Yayımlanmamıs yüksek lisans tezi, İstanbul Kültür Üniversitesi Sosyal Bilimler Enstitüsü, İstanbul. 
Tatar, İ. (2016). “Öğretmen Adaylarının Medya Okuryazarlığı ile Çevrimiçi Bilgi Arama Stratejileri Arasındaki İlişkinin İncelenmesi.” Yayımlanmamış yüksek lisans tezi, Anadolu Üniversitesi Eğitim Bilimleri Enstitüsü, Eskişehir.

Talim ve Terbiye Kurulu Başkanlığı (2013). 239 No'lu Talim ve Terbiye Kurulu Başkanlığı Kararı. https://ttkb.meb.gov.tr/www/gecmisten-gunumuze-kurulkararlari/icerik/152 adresinden erişilmiştir.

Türk, G. D. (9-11 Aralık 2013). Demokrasinin Dördüncü Kuvveti Yeni Medya Teknolojileri. XVIII. Türkiye'de İnternet Konferansı'nda sunulmuş bildiri, İstanbul.

Yıldırım, A. ve Şimşek, H. (2013). Sosyal Bilimlerde Nitel Araştırma Yöntemleri. (9. Genişletilmiş Baskı). Ankara: Seçkin Yayıncılık. 


\section{Comparison of the 2006 and 2013 Media Literacy Curricula from the Teacher's Point of View ${ }^{1}$}

\begin{tabular}{lccc}
\hline $\begin{array}{l}\text { ARTICLE TYPE } \\
\text { Research Article }\end{array}$ & $\begin{array}{c}\text { Received Date } \\
10.10 .2017\end{array}$ & $\begin{array}{c}\text { Accepted Date } \\
07.06 .2018\end{array}$ & $\begin{array}{c}\text { Online First Date } \\
07.07 .2018\end{array}$ \\
\hline \multicolumn{4}{c}{ Pınar Tağrikulu iD $\mathbf{2}$ and Alper Kesten iD } \\
Ondokuzmayıs University
\end{tabular}

\section{Abstract}

A media literacy course aims to enable students to reach a specific consciousness towards media. Following studies investigating inclusion of this course in the curriculum, a program was prepared and, following adjustments, a second newer program was formulated in 2013. In this study, teachers were asked to assess the media literacy curriculum in terms of attainment, skills, values, activities and measurement and evaluation. In order to collect data, the study used an interview method, and a qualitative research method, with the data obtained being assessed using the descriptive analysis technique. In general, it was found that teachers thought that the 2013 curriculum was more extensive and more functional than the 2006 curriculum. At this point, it was found that the teachers who had assessed the 2013 program positively pointed out that the content of the curriculum was lighter and that it benefitted from a structure which allowed for measurement and evaluation.

Keywords: Media literacy, secondary school, curriculum, mass communication

\footnotetext{
${ }^{1}$ This study was produced from a Master Thesis entitled, 'The New Media Literacy Program from the Teacher's Point of View'.

${ }^{2}$ Corresponding author: Research Assisstant, Department of Turkish and Social Sciences Education, pinar.tagrikulu@omu.edu.tr, https://orcid.org/0000-0002-5221-6888

3 Associate Professor, Department of Turkish and Social Sciences Education, akesten@omu.edu.tr, https://orcid.org/0000-0003-2657-3168
} 


\section{Purpose and Significance}

A media literacy course curriculum prepared in 2006 was revised in 2013. Although there have been many studies regarding the Media Literacy Teaching Program introduced in 2006, there are few studies concerning to what extent the 2013 Media Literacy Teaching Program meets expectations, how the new program is applied in schools, how teachers and students react to the lessons and what problems arise in the application of the new program. This study compares the updated Media Literacy Teaching Program with the previous teaching program. For this purpose, not only opinions regarding the 2006 Program were uncovered, but teachers' opinions concerning the 2013 Program were also taken. In this way, a detailed assessment was made covering both teaching programs. In this aspect, it is thought that the study will contribute to the relevant literature in the field of media literacy. The purpose of this study is to show whether the renewed curriculum solves the problems resulting from the old curriculum and to make suggestions about how the new curriculum could be improved. Within this context, it is thought that suggestions for the new curriculum in particular can contribute to studies aimed at improving the curriculum.

\section{Method}

The study group consists of twelve teachers teaching media literacy at ten primary and secondary schools of the Turkish province of Samsun. In order to collect data, the study used an interview method, which is a qualitative research method. The validity and reliability of the questions in the interview forms prepared for this study were tested on the teachers in the study group by pre-interview by a teacher teaching media literacy and making required edits in the interview form. This interview was conducted to find the validity and reliability of the questions left out of the interviews of teachers in the study group. In addition, for the validity and reliability of the data obtained, the study was finalized in line with the views of two expert academics in the field, by presenting analyses and comments to another independent researcher.

Permission to collect data was taken from the authorized institutions and participants were asked questions to assess both programs. The interviews were conducted in settings such as a teachers' staff room and classrooms in the school. Problems were encountered, such as interviews being interrupted by noise and outside questions being put to teachers. However, these did not interfere with the answering of questions on the interview form. Within this context, the teachers were first asked to explain their opinions regarding the attainments, skills, values, activities, measurement and evaluation dimensions of the 2006 Media Literacy Teaching Program. Later, the teachers were asked to assess the 2013 Media Literacy Teaching Program from the same perspective. For all dimensions of both programs, there were teachers who gave positive opinions as well as teachers who gave negative opinions. All the interviews were recorded using voice recorders. In an analysis of interview data, each teacher was given code names, T1, T2, T3 ...T12, and the interviews were assessed using a descriptive analysis technique. 


\section{Results}

In this section, including interviews with the teachers, both programs are assessed through the opinions of teachers. In general, the attainments of the 2006 Program are assessed as more negative than the attainments of the 2013 Program. The teachers who assessed the skills dimension of the 2006 Program stated that since this program requires an intense knowledge transfer to students, it is insufficient for teaching skills. In terms of values, both programs were assessed positively. In terms of activities, the 2006 Program was assessed more negatively than the 2013 Program. It was mentioned that the 2013 Program included more activities and also included students in the process. The teachers also noted that by starting to grade the media literacy course in the 2013 Program, the course began to be taken more seriously by students. However, it was also mentioned that there were aspects to be developed in the 2013 Program. Some of the participants stated that attainments suitable for the time allocated to lessons, and suitable for knowledge and comprehension levels, wereincluded, and assessed the attainments of the 2006 Media Literacy Teaching Program positively. A number of the teachers who assessed attainments positively thought that the time allocated to all media tools was sufficient and stated that this made it easier for them to teach. Some of the teachers discussing attainments stated negative opinions saying that the attainments were not applicable, that they were intense and that they were only at an informative level. The most criticized aspect of the program is it not being applicable. The teachers who discussed the skills in the 2006 Program state that the program was successful in terms of skills. The teachers further state that it included applicable skills which made students effective and which students could use in their daily lives. Teachers who assessed the skills in the 2006 Program negatively stated that these skills did not make students effective, that they were not applicable, and that they were just at an informative level. They considered these skills to be insufficient.

The teachers who assessed the measurement and evaluation dimension of the 2006 Program positively expressed positive views saying that it was easy to measure and evaluate lessons and that it allowed for different measurement and evaluation activities. A number of the teachers expressed negative opinions, stating an absence of an examination, students not participating in productive skills and students not receiving a grade from the course in their school reports. The teachers who assessed the activities in the 2006 Program positively stated that the activities set the teacher and students free and they could be taught within the time frame. However, three of the teachers gave negative opinions stating that students were not effective and that the activities were limited and insufficient. The teachers who assessed values in the 2006 Program thought positively that it was remarkable for the program to address values that children could use in their daily lives and to emphasize moral values. The teachers who assessed values in the 2006 Program thought negatively that these values were insufficient and above the students' level. 
The opinions of teachers who assessed the 2013 Program centred positively on the view that the program enabled students to participate actively in the program. The participants stated that the program was suitable in terms of giving skills to students. The easy applicability of the program, not having too many subjects and being fun were among reasons the teachers evaluated the program positively. In addition to participants who assessed the 2013 Program positively, there were also participants who assessed the 2013 Program negatively. The teachers who assessed the program positively stated that attainments were not very detailed, that they were simplified and that they were suitably constructed for the students' level. The teachers stated that the attainments in this program enabled students to produce their own media messages, were student-centred, enabled students to act on their own initiative, were suitable for the times, and that they were applicable, effective and well-planned. The aspects considered as positive by teachers who assessed the skills of the 2013 Program were that the program included skills which made students effective and skills which were easy to measure, as well as skills which enabled students to research, examine, observe, solve and produce. A teacher who assessed the skills in the 2013 Program negatively stated that the program was inadequate in giving skills to students. The teachers who assessed values in the 2013 Program stated that these values were prepared through extremely hard work and that they enabled the education of students in a responsible way. The teachers who assessed the values negatively stated that they were incomplete, were not applicable and that it was not possible to teach them to students effectively due to the limited number of lesson hours. The participants who discussed the activities in the 2013 Program stated that these activities were useful, student-centred, allowed for examination, could be used in other lessons and that they could motivate students during lessons. The teachers who assessed the activities of the 2013 Program negatively stated that they were insufficient, high level, difficult and not applicable and that it was not possible for students to conduct these activities alone. The same teachers stated that the time allocated for these activities was insufficient.

\section{Discussion and Conclusion}

The fact that the 2013 Program adopted a constructivist approach, included more activities and realized measurement and evaluation through examination led to positive assessments of the program. However, the fact that the course was offered as an elective course and that it is unclear who would teach the course are some of the problems that remain unsolved. Therefore, the teachers involved should be given inservice training, the course should be made compulsory, questions regarding this course should be asked in central exams, and the Media Literacy Activity Book should be published for the course. 